\title{
The 3D Cell Culture System in the Study of Tumor-Applications and Prospects
}

\author{
Huizhen Yang*\#, Jiaqi Jiao\# \\ School of Basic Medicine, Shanxi Medical University, Taiyuan, China \\ Email: *15735011935@163.com
}

How to cite this paper: Yang, H.Z. and Jiao, J.Q. (2018) The 3D Cell Culture System in the Study of Tumor-Applications and Prospects. Journal of Biosciences and Medicines, 6, 36-43.

https://doi.org/10.4236/jbm.2018.69004

Received: August 14, 2018

Accepted: September 11, 2018

Published: September 14, 2018

Copyright $\odot 2018$ by authors and Scientific Research Publishing Inc. This work is licensed under the Creative Commons Attribution International License (CC BY 4.0).

http://creativecommons.org/licenses/by/4.0/

\begin{abstract}
Compared with 2D tumor cell culture, 3D tumor cell culture can better simulate the microenvironment of signal transduction between cells and extracellular matrix. As one of the best cell models in tumor research, it has been widely used in the study of cancer cell morphology, nanotechnology drug delivery system, and anticancer drug screening. The main theme of this paper is to review the previous research of $3 \mathrm{D}$ cell culture applying to tumors in vitro and the prospects for the applications of $3 \mathrm{D}$ cell culture system.
\end{abstract}

\section{Keywords}

3D Cell Culture System, 2D Cell Culture System, In Vitro Tumors

\section{Introduction}

2-dimensional (2D) culture means a method of culturing tutors by building models outside the body in two dimensions. Regarding as the 3-dimensional (3D) culture, it is also a way to culture tissues but one more dimension than $2 \mathrm{D}$ culture. In vitro, tumoris anartificial tissue, is established outside of bodies as a model to culture in vitro tumors for better tumor research.

The previous work on the three-dimensional (3D) cell culture system has indicated that the morphology and function of isolated cells in 3D culture are closer to the real growth state of these cells in vivo comparing the traditional two-dimensional (2D) cell culture [1]. Due to the highly abnormal graphic and mechanical constraints compelled on cells in 2D cultures could alter cellular interactions with the extracellular matrices (ECM) and the signaling pathway; $2 \mathrm{D}$ cell cultures cannot simulate the cellular properties of normal tissues. In addition, 2D cell culture oversimplifies the various processes that Nano-medicine reaches its targeted site in vivo.

\#Contributed equally, signature by the alphabetical order of names. 


\subsection{Features of 3D Cell Culture}

Tumor cells are closer to the tumor microenvironment under 3D culture conditions, showing more characteristics of tumors in the body. The 3D culture of tumor cells can form a hollow tissue necrosis area similar to that of the tumor tissue in the body, which is often significantly different from the surrounding nutrient and oxygen supply areas [2]. More importantly, the growth of tumor cells in 3D culture is relatively slower than that of monolayer cells, and is therefore more representative of the physiological growth of tumor cells [3]. In addition, it has been found that tumor cells have obvious advantages in morphology, signal transduction, cell proliferation, growth and differentiation, and response to therapeutic stimulus under 3D conditions [3].

\subsection{Advantages and Disadvantages of 3D Cell Culture}

Shown in Table 1, by comparing the effects of $2 \mathrm{D}$ and $3 \mathrm{D}$ culture on some aspects of cell growth, it is clear that $2 \mathrm{D}$ culture has an inevitable limitation in application, especially in the study of microenvironment and cell interaction. As we all known, human beings live in a three-dimensional world. Human body tissues are also a complex 3D configuration. Various substances act to connect and transmit information, thereby regulating various functions of cells. 3D culture is also based on the above reasons, and has the advantage that $2 \mathrm{D}$ cannot be compared. In 2D cell culture, the microenvironment of monolayer growth is not sufficient to fully mimic the conditions of growth in vivo. The data obtained under the 2D model cannot explain the research very clearly, so in order to obtain the information in the $3 \mathrm{D}$ culture as much as possible, it is necessary to have enough samples to cultivate a large number of $3 \mathrm{D}$ culture models, and it is difficult to analyze the data.

Although 3D culture technology has many advantages, which are beyond 2D, classical 2D culture still occupies a large proportion in the in vitro culture mode. On the one hand, after more than 30 years of development and improvement of

Table 1. The comparison of 2-dimensional culture and 3-dimensional culture.

\begin{tabular}{|c|c|c|}
\hline $\begin{array}{l}\text { Cellular and } \\
\text { microenvironmental } \\
\text { features }\end{array}$ & 2-dimensional culture & $\begin{array}{l}\text { 3-dimensional culture } \\
\text { (advantages) }\end{array}$ \\
\hline Cell morphology & $\begin{array}{l}\text { Typically flattened and } \\
\text { unconstrained spreading } \\
\text { on the substrate }\end{array}$ & $\begin{array}{l}\text { Depending on the adhesion ligands used, } \\
\text { cells can be spherical, spindle shaped or } \\
\text { exist as multicellular aggregates }\end{array}$ \\
\hline $\begin{array}{l}\text { Cytoskeletal } \\
\text { structure }\end{array}$ & $\begin{array}{l}\text { Display thick bundles of } \\
\text { well-developed ventral } \\
\text { stress fibers }\end{array}$ & $\begin{array}{c}\text { Few thin stress fibers found } \\
\text { near the cell cortex }\end{array}$ \\
\hline $\begin{array}{l}\text { Gene and protein } \\
\text { expression }\end{array}$ & $\begin{array}{l}\text { Similarities with in vivo } \\
\text { counterparts are lacking }\end{array}$ & Generally more in vivo-like \\
\hline Cell differentiation & $\begin{array}{l}\text { Two-dimensional inducts } \\
\text { cell differentiation }\end{array}$ & $\begin{array}{l}\text { Three-dimensional space is closer to the } \\
\text { intracellular microenvironment }\end{array}$ \\
\hline
\end{tabular}


2D culture, it has formed a standardized research mode. On the other hand, 3D is still a relatively new technology. Although $3 \mathrm{D}$ culture has been applied in some researches, it is more in the experimental stage. This phenomenon is due to some technical difficulties in the development of 3D culture technology.

1) It is difficult to establish $3 \mathrm{D}$ culture materials. Natural materials with suitable diameters often have some uncontrollable residues such as growth factors and unknown impurities, which will affect the final experimental data to varying degrees. At present, many materials are synthesized from known components. Some researchers have used synthetic materials to establish 3D cultures, such as Puramatrix [4], synthetic hydrogel system [5] etc. Applied in 3D culture studies, but there is still no standardized synthetic material. Therefore, it is important to develop suitable scaffold materials for constructing 3D culture.

2) Since $3 D$ culture is one more layer than $2 D$ culture, the amount of information is much larger than 2D culture, so when extracting a large amount of effective information, a higher level of technology such as high permeability and high resolution chemical or fluorescent labeling is required. At present, automated processes have been applied to laboratories in the inoculation of primary cells in $3 \mathrm{D}$ culture to improve research efficiency, which tackles these problems in some degree. So this is also one of the difficulties that the current research needs to overcome.

\section{Application of 3D Cell Culture}

My partner and I grabbed the main idea of the article, as shown in Figure 1. We searched all major databases for meaningful articles with the keywords "tumor" and "3D technology". Then we read all articles carefully to write articles.

As an effective means of drug and biological research, three-dimensional (3D) cell culture systems have received extensive attention. The main advantages of biological effects in 3D culture model for tumor research shows in three aspects.

\subsection{Establishing an Ideal Research Tumor Model}

The tumor microenvironment is vital for tumor cells to survive. It is well known

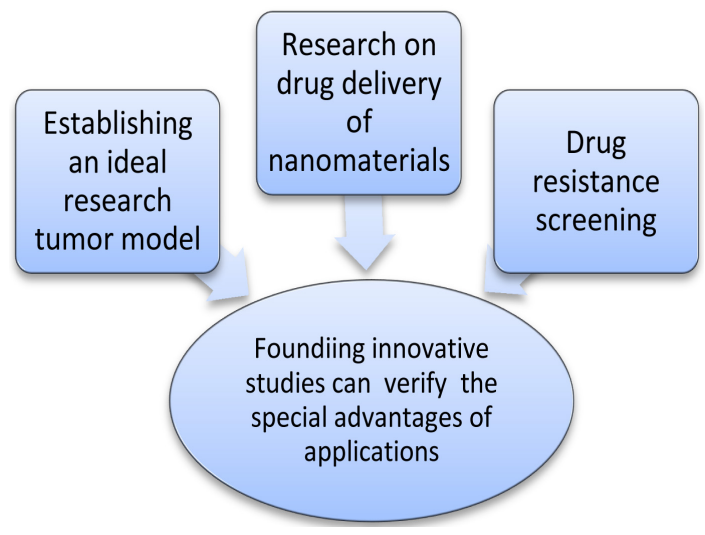

Figure 1. The choice of papers. 
that it contains a series of complex mixtures, all kinds of cells and ECM such as oligopeptides and enzymes. There are some mutual stimulation and tumor cells. Although two-dimensional culture is still a reliable culture model reflecting cell proliferation and migration, there are still many deficiencies in the interaction between tumor cell growth, proliferation, metastasis and invasion. In addition, single-layer planar cultured tumor cells are rearranged through cell stents to obtain artificial cell polarity, resulting in abnormal gene and protein expression of tumor cells [6].

In contrast, when cells are cultured in $3 \mathrm{D}$, due to their $360^{\circ}$ surround interaction, their internal procedures are initiated to restore their former memories in their native tissue structure. Previous experiments by Sheff D have suggested when epithelial cells grow in a 3D cell culture model, they can "intuitively" reorganize themselves into apical and basal lateral orientations, which have characteristic columnar arrangements [7]. The cavity side of these epithelial cells can be arranged perpendicular to or parallel to gravity or any other direction between these two extremes, and the entire "tissue" structure is functionally notified. This is the reason why the results of the $3 \mathrm{D}$ culture experiment are closer to the microenvironment in the body. 3D cultured cells form dense tissue clusters and have spatial degrees of freedom to form more diverse cell orientations, partly due to they are not attached to a single planar substrate, and this freedom causes cells to reassemble lost natural interactions. Therefore, 3D cell culture as a model for in vitro study of tumors can simulate the microenvironment of tumors in the body and be used for the study of tumor cell behavior in vivo [8]. Studies have shown that the tumor microenvironment is related with malignant progression of breast cancer, Hyaluronan (HA), as the main part of the extracellular matrix, plays a critical role in tumor angiogenesis, invasion, and metastasis. Some scholars have established a 3D culture system through covalently cross-linked HA. This environment facilitates completely distinct cellular behavior compared to $2 \mathrm{D}$ culture systems. The malignancy and drug resistance of tumor cells and differentiation ability and expression of stemness genes is strongly enhanced when cultured in 3D scaffolds. It is very beneficial to study the role of HA with different molecular weights (MWs) on breast cancer cell invasion [9].

\subsection{Research on Drug Delivery of Nanomaterials}

At present, in the $2 \mathrm{D}$ environment, the use of a single in vitro cell to optimize the biological behavior in the body is quite limited; there have been many failures in vivo three-dimensional biological and physicochemical behavior by using in vitro cell assays. Therefore, the utilization of $3 \mathrm{D}$ cell culture systems for nano-medicine screening is expected to take on the role of the bridge to close up the gap between $2 \mathrm{D}$ cell culture work and the pre-clinical stages of animal works. Experiments have proved that nano-materials have the potential ability of $3 \mathrm{D}$ models for drug delivery, so it might be promising for the in vitro prediction of 
3D behavior of drugs and drug carriers [10].

It's limited use of traditional 2D cell culture techniques. The cell culture method should use a supporting scaffold equivalent to the cytoplasmic matrix. Researchers demonstrate the advantages of novel nano-structured 3D grids fabricated using electro-spinning technique, as scaffolds for cultures of neoplastic cells. The results show that the fibers allow for a dynamic growth of HeLa cells, forming multi-layer structures of symmetrical and spherical character. And it is proved that grids can be used to examine the cell ultrastructure in situ [11].

\subsection{Drug Resistance Screening}

In the most recent years, 3D fine cell culture technology have shown incomparable advantage in the field of drug research and development, especially the evaluation of drug safety [12] and the study of new drug screening [13]. With the development of 3D culture technology in vitro, researchers have gradually realized that because cells form a 3D environment together with the ECM in the body, the planar biological characteristics of cells in 2D planar culture in vitro are significantly different from those in the body. So the experimental results are different from the actual results. In vitro, it is an inevitable trend to construct a $3 \mathrm{D}$ tumor model to substitute the traditional 2D tumor model for drug screening.

The most promising drugs do not have further clinical trials, in part because many $2 \mathrm{D}$ experiments fail to reflect the $3 \mathrm{D}$ interaction between solid tumor cells and the matrix [14]. Most scholars are currently working on establishing a universal 3D cancer culture and screening device to ensure a high degree of flexibility in selecting well-developed 3D culture methods and screening methods for any cell sample. Previous experiments by Miriam Widder, a modified 384-well-device for investigations of tumor biology was established, through higher reproducibility and the ability for high-throughput analyses, the screening and treatment of cancer cells have a good effect [15]. Now, the most popularly used 3D tumor model is a multicellular sphere. Using this model, the spherical diameter, cytotoxic effects, and drug penetration rates can be analyzed, and different anti-tumor drugs can be screened and studied [16]. Godugu [17] has constructed a bulging spherical sieve selection model based on alginate; though the analysis of the evaluation, cytotoxicity, apoptosis, and the infiltration of nanoparticles into tumor cells in vitro, the anti-swollen tumor drugs were selected for screening and research during the use of different materials.

\section{Design and Results of Other Related Experiments}

At present, some scholars have made various attempts to apply 3D technology, as shown in Table 2, which is of great reference significance for the development of our future medical industry.

\section{Future Prospects}

To sum up, 3D cell culture shows incomparable advantages in simulating tumor 
Table 2. Other relevant results of the experimental.

\begin{tabular}{|c|c|c|c|c|}
\hline $\begin{array}{c}\text { Experimental } \\
\text { model }\end{array}$ & Solved disease & $\begin{array}{c}\text { Experimental } \\
\text { material }\end{array}$ & $\begin{array}{l}\text { The experimental } \\
\text { results }\end{array}$ & Reference \\
\hline $\begin{array}{c}\text { 3D } \\
\text { human-tissue } \\
\text { models }\end{array}$ & Atherosclerosis & $\begin{array}{l}\text { Paclitaxel } \\
\text { (PTX) }\end{array}$ & $\begin{array}{l}\text { It suggested excellent } \\
\text { biological } \\
\text { characteristics and } \\
\text { potential treatment } \\
\text { effects of the } \\
\text { nanoparticles } \\
\text { optimized in vitro }\end{array}$ & [1] \\
\hline $\begin{array}{l}\text { 3D model set up } \\
\text { by crosslinking } \\
\text { HA with } \\
\text { alginate }\end{array}$ & Breast cancer & $\begin{array}{l}\text { Hyaluronan } \\
\qquad(\mathrm{HA})\end{array}$ & $\begin{array}{l}\text { The invasion and } \\
\text { migration abilities of } \\
\text { 4T-1 and SKBR3 cells } \\
\text { are significantly } \\
\text { enhanced by the } \\
\text { presence of HA35 }\end{array}$ & [2] \\
\hline $\begin{array}{l}\text { nanostructured } \\
\text { 3D grids } \\
\text { fabricated using } \\
\text { electro-spinning } \\
\text { technique }\end{array}$ & $\begin{array}{l}\text { Screening of } \\
\text { new drugs }\end{array}$ & $\begin{array}{l}\text { Electrospun } \\
\text { scaffolds }\end{array}$ & $\begin{array}{l}\text { The scaffolds are } \\
\text { transparent and thus } \\
\text { allow observation of } \\
\text { viable cells in time; } \\
\text { standard fluorescence } \\
\text { or colorimetric me- } \\
\text { thods such can be used } \\
\text { for evaluation of cells }\end{array}$ & [6] \\
\hline $\begin{array}{c}\text { Inflamed } \\
\text { mucosa model } \\
\text { (colon) }\end{array}$ & $\begin{array}{l}\text { Chronic IBD } \\
\text { (colon) }\end{array}$ & $\begin{array}{l}\text { Budesonide/ } \\
\text { fluoreceinamine }\end{array}$ & $\begin{array}{c}\text { Prolonged } \\
\text { anti-inflammatory } \\
\text { effect was } \\
\text { observed for } 4 \text { days }\end{array}$ & [18] \\
\hline 3D skin model & Skin & Squalene & $\begin{array}{l}\text { Superior defensive and } \\
\text { anti-wrinkle actions of } \\
\text { squalane loaded } \\
\text { fullerene-C60 } \\
\text { was reported }\end{array}$ & [19] \\
\hline
\end{tabular}

microenvironment, nanodrug delivery and drug screening. At present, a variety of bio-simulated 3D tumor models have been widely used, such as the 3D culture resistance model of breast cancer cells [20], the 3D culture model of OSCC-3 [21], the 3D skin model [22], and the 3D blood and brain barrier model in vitro [23].

However, it is still has many flaws. Many models still do not accurately reflect the pathological characteristics of the initial disease and some tumor models are only morphologically similar to native tumor tissues, lacking complex cell signals and complex biological behaviors. With the development of 3D cell culture technology, tumor models are becoming more and more complex. They urgently need to participate in multiple disciplines such as mathematical modeling, tumor genomics, and system biology. The researcher will gradually overcome the shortcomings of 3D models and show great potential for pre-clinical research advantages. 


\section{Fund Project}

Innovation and Entrepreneurship Training Graduate Project (2018162).

\section{Conflicts of Interest}

The authors declare no conflicts of interest regarding the publication of this paper.

\section{References}

[1] Karki, S.B., Thapa Gupta, T., Yildirimayan, E., et al. (2017) Investigation of Non-Thermal Plasma Effects on Lung Cancer Cells within 3D Collagen Matrices. Journal of Physics D: Applied Physics, 50. https://doi.org/10.1088/1361-6463/aa7b10

[2] Infanger, D.W., Lynch, M.E., Fischbach, C., et al. (2013) Engineered Culture Models for Studies of Tumor-Microenvironment Interactions. Annual Review of Biomedical Engineering, 15, 29-53. https://doi.org/10.1146/annurev-bioeng-071811-150028

[3] Zhang, Y.T., Lu, W., Li, T., et al. (2008) A Continued Study on the Stealth Liposomal Topotecan plus Amlodipine: In Vitro and in Vivo Characterization in Non-Resistant Solid Tumors. Journal of Health Science, 54, 450-463. https://doi.org/10.1248/jhs.54.450

[4] Zhang, S., Yokoi, H., Gelain, F., et al. (2012) Designer Self-Assembling Peptide Nanofiber Scaffolds. In: Silva, G. and Parpura, V., Eds., Nanotechnology for Biology and Medicine, Springer, New York, 123-147. https://doi.org/10.1007/978-0-387-31296-5_6

[5] Lutolf, M.P. (2009) Biomaterials: Spotlight on Hydrogels. Nature Materials, 8, 451-453. https://doi.org/10.1038/nmat2458

[6] Fong, S., Chan, M.K., Fong, A., Bowers, W.J. and Kelly, K.J. (2010) Viral Vector-Induced Expression of Bone Morphogenetic Protein 2 Produces Inhibition of Tumor Growth and Bone Differentiation of Stem Cells. Cancer Gene Therapy, 17, 80-85. https://doi.org/10.1038/cgt.2009.56

[7] Sheff, D., Pelletier, L., O’Connell, C.B., Warren, G. and Mellman, I. (2002) Transferrin Receptor Recycling in the Absence of Perinuclear Recycling Endosomes. Journal of Cell Biology, 156, 797-804. https://doi.org/10.1083/jcb.20111048

[8] Tay, C.Y., Muthu, M.S., Chia, S.L., et al. (2016) Reality Check for Nanomaterial-Mediated Therapy with 3D Biomimetic Culture Systems. Advanced Functional Materials, 26, 4046-4065. https://doi.org/10.1002/adfm.201600476

[9] Zhao, Y., Qiao, S., Shi, S., et al. (2017) Modulating Three-Dimensional Microenvironment with Hyaluronan of Different Molecular Weights Alters Breast Cancer Cell Invasion Behavior. ACS Applied Materials \& Interfaces, 9, 9327-9328. https://doi.org/10.1021/acsami.6b15187

[10] Chetprayoon, P., Matsusaki, M., Yokoyama, U., et al. (2016) Use of Three-Dimensional Arterial Models to Predict the in Vivo Behavior of Nanoparticles for Drug Delivery. Angewandte Chemie, 128, 4537-4542. https://doi.org/10.1002/ange.201509752

[11] Wolun-Cholewa, M., Langer, K., Szymanowski, K., et al. (2013) An Efficient 3D Cell Culture Method on Biomimetic Nanostructured Grids. PloS ONE, 8, e72936. https://doi.org/10.1371/journal.pone.0072936

[12] Godugu, C., Pater, A., Desai, U., et al. (2013) AlgiMatrix ${ }^{\mathrm{TM}}$-Based 3D Cell Culture System as an in-Vitro Tumor Model for Anticancer Studies. PLOS ONE, 8, e53708. 
https://doi.org/10.1371/journal.pone.0053708

[13] Longati, P., Jia, X., Eimer, J., et al. (2013) 3D Pancreatic Carcinoma Spheroids Induce a Matrix Rich, Chemoresistant Phenotype Offering a Better Model for Drug Testing. BMC Cancer, 13, 95. https://doi.org/10.1186/1471-2407-13-95

[14] Hickman, J.A., Graeser, R., de Hoogt, R., Vidic, S., et al. (2014) Three-Dimensional Models of Cancer for Pharmacology and Cancer Cell Biology: Capturing Tumor Complexity in Vitro/ ex Vivo. Biotechnology Journal, 9, 1115-1128. https://doi.org/10.1002/biot.201300492

[15] Widder, M., Lemke, K., Kekeç, B., et al. (2017) A Modified 384-Well-Device for Versatile Use in 3D Cancer Cell (Co-)Cultivation and Screening for Investigations of Tumor Biology in Vitro. Engineering in Life Sciences, 18, 132-139. https://doi.org/10.1002/elsc.201700008

[16] Nath, S. and Devi, G.R. (2016) Three-Dimensional Culture Systems in Cancer Research: Focus on Tumor Spheroid Model. Pharmacology \& Therapeutics, 163, 94-108. https://doi.org/10.1016/j.pharmthera.2016.03.013

[17] Godugu, C. and Singh, M. (2016) AlgiMatrix ${ }^{\mathrm{TM}}$-Based 3D Cell Culture System as an in Vitro Tumor Model: An Important Tool in Cancer Research. Cancer Chemoprevention. Springer, New York, 117-128.

[18] Leonard, F., Ali, H., Collnot, E.M., et al. (2012) Screening of Budesonide Nanoformulations for Treatment of Inflammatory Bowel Disease in an Inflamed 3D Cell-Culture Model. Altex, 29, 275.

[19] Kato, S., Aoshima, H., Saitoh, Y., et al. (2010) Defensive Effects of Fullerene-C60 Dissolved in Squalane against the 2,4-Nonadienal-Induced Cell Injury in Human Skin Keratinocytes HaCaT and Wrinkle Formation in 3D-Human Skin Tissue Model. Journal of Biomedical Nanotechnology, 6, 52-58. https://doi.org/10.1166/jbn.2010.1091

[20] Kim, J.B., Stein, R. and O'Hare, M.J. (2004) Three-Dimensional in Vitro, Tissue Culture Models of Breast Cancer-A Review. Breast Cancer Research \& Treatment, 85, 281-291. https://doi.org/10.1023/B:BREA.0000025418.88785.2b

[21] Fischbach, C., Chen, R., Matsumoto, T., et al. (2007) Engineering Tumors with 3D Scaffolds. Nature Methods, 4, 855. https://doi.org/10.1038/nmeth1085

[22] GãTz, C., Pfeiffer, R., Tigges, J., et al. (2012) Xenobiotic Metabolism Capacities of Human Skin in Comparison with a 3D Epidermis Model and Keratinocyte-Based Cell Culture as in Vitro Alternatives for Chemical Testing: Activating Enzymes (Phase I). Experimental Dermatology, 21, 358-363. https://doi.org/10.1111/j.1600-0625.2012.01486.x

[23] Hatherell, K., Couraud, P.O., Romero, I.A., et al. (2011) Development of a Three-Dimensional, All-Human in Vitro Model of the Blood-Brain Barrier Using Mono-, Co-, and Tri-Cultivation Transwell Models. Journal of Neuroscience Methods, 199, 223. https://doi.org/10.1016/j.jneumeth.2011.05.012 